\title{
Low-cost test setup for motorcycle protective clothing abrasion examination
}

\author{
Dietrich Spädt' ${ }^{1}$, Imane Moulefera $^{2}$, Al Mamun ${ }^{3}$, Marah Trabelsi ${ }^{4}$, Lilia Sabantina ${ }^{3, *}$ \\ 1 Faculty of Engineering and Mathematics, Bielefeld University of Applied Sciences, 33619 Bielefeld, Germany \\ 2 L.M.A.E. Laboratory, University of Mustapha Stambouli Mascara, 29000 Mascara, Algeria \\ 3 Junior Research Group "Nanomaterials", Faculty of Engineering and Mathematics, Bielefeld University of Applied \\ Sciences, 33619 Bielefeld, Germany \\ ${ }^{4}$ Laboratoire de Génie des Matériaux et Environnement (LGME), Ecole Nationale d'Ingénieurs de Sfax (ENIS), \\ Sfax 3038, Tunisia \\ *Corresponding author E-mail address: lilia.sabantina@fh-bielefeld.de
}

\section{INFO}

CDAPT, ISSN 2701-939X

Peer reviewed article

2021, Vol. 2, No. 2, pp. 196-207

DOI 10.25367/cdatp.2021.2.196-207

Received: 10 November 2021

Accepted: 16 December 2021

Available online: 17 December 2021

\begin{abstract}
The personal protective equipment and protective clothing for motorcyclists reduce physical injuries to victims of road accidents. Therefore, it is important that the protective clothing complies with a number of test standards, which must be taken into account during the manufacturing process. However, the EN17092-1 to 6 standard does not necessarily correspond to a real accident situations and these testing procedures are time consuming. In this study, a simple and inexpensive self-constructed device for testing the abrasion resistance of motorcycle protective clothing was developed and evaluated. Different types of textiles and leather with and without coating were tested and compared. According to the results of this study, not only leather but also textiles offer good abrasion resistance results. The results show that the strength of an impact significantly changes the abrasion resistance. The developed test method can provide a good alternative as a low-cost and simple test method of abrasion resistance of motorcycle protective clothing.
\end{abstract}

\section{Keywords}

low-cost test setup,

motorcycle protective clothing,

abrasion examination,

textiles,

self-build set-up

(C) 2021 The authors. Published by CDAPT.

This is an open access article under the CC BY-NC-ND license https://creativecommons.org/licenses/ peer-review under responsibility of the scientific committee of the CDAPT.

(C) 2021 CDAPT. All rights reserved.

\section{Introduction}

Motorcyclists, like cyclists, are among the most vulnerable road users, which is why the issue of safety plays a major role here [1]. While there are new innovations in safety, such as helmets made of biobased materials or airbags integrated into helmets, which require intensive research, most of them are 
affordable only for a small part of the population [2,3]. On the other hand, motorcycle riders benefit from the safety systems in their vehicles, which include airbags, but also many other safety-related systems. In motorcycles, these safety systems are less present due to the lack of a buffer zone between the motorcyclist and the environment [4]. Comparing the number of protective systems in these vehicles and the resulting safety features, it can be noted that motorcyclists inevitably rely on good protective clothing, which must absorb a significant amount of impact energy $[5,6]$. The protective clothing is an important safety factor and is designed to provide the rider with a protective function without sacrificing mobility. It is encouraging to note that the number of motorcyclist fatalities decreased by $15.1 \%$ in 2019 , representing a decrease of 105 fatalities [7]. It is obvious that protective clothing from new fabrics/textiles must be safe and the standards such as EN17092-1 to 6 or EN 1621-3:2019-03 (chest protectors for motorcyclists) [8-10] are important for this purpose. Motorcycles can be divided into different product groups, such as super sports bikes and tourers or off-roaders. The EN17092-1 to 6 series of standards contains a total of five protection classes with differently assigned load requirements $[8,9]$. The load requirements include, for example, abrasion resistance, tensile strength and tear resistance as well as damping in the event of an impact [9]. The distinction between the protection classes makes sense because a racetrack driver needs different protection than a recreational driver [10-11]. The European standard EN13595 for motorcycle protective clothing contains test methods and performance criteria and was used for a long time. In 2019, the European Commission mandated that all motorcycle clothing sold in Europe must be tested and a new standard EN17092 1:2020 for motorcycle jackets and pants was developed. The overview of the European standard EN13595-2 and 17092-1 and test methods is shown in Table 1.

Table 1. Test standards for motorcycle clothing.

\begin{tabular}{|c|c|}
\hline European Standard & Test method \\
\hline $\begin{array}{l}\text { EN 13595-2 "Part 2: Test method } \\
\text { for determination of impact } \\
\text { abrasion resistance" }\end{array}$ & $\begin{array}{l}\text { - The Taber® Abraser device which is designed for accelerated } \\
\text { - } \text { A tear testing is used. } \\
\text { sliding rotations of two friction wheels rotating in vertical planes. } \\
\text { - Combination of rolling friction and dynamic friction at low } \\
\text { pressure [11]. }\end{array}$ \\
\hline $\begin{array}{l}\text { EN 17092-1:2020 "Motorcyclist } \\
\text { Protective Clothing - Part 2" } \\
\text { (Darmstadt method) }\end{array}$ & $\begin{array}{l}\text { - Simulation of the fall of a motorcyclist and subsequent sliding to } \\
\text { a standstill. } \\
\text { - The rotational sliding with the fall simulation is imitated. }\end{array}$ \\
\hline
\end{tabular}

As can be seen from the description of the test methods, an attempt is made to determine the abrasion resistance of motorcycle clothing and various test inserts are selected for this purpose. In EN 13595-2, a combination of rolling friction and sliding friction at low pressure is used, which of course does not necessarily correspond to the real conditions in the event of an accident. The Darmstadt method is also subject to certain limits, as abrasion in the test process creates a certain film of abrasion on the concrete or the road surface, which leads to a falsification of the result. The Darmstadt method is usually used to evaluate the impact abrasion resistance of clothing materials at specific driving speeds.

Therefore it makes sense to develop new and different methods for motorcycle clothing to offer protection against injuries and to take into account the aspects of freedom of movement of the motorcyclist without tiring or stressing the body. Personal protective equipment and protective clothing for motorcyclists form a protection of motorcyclists to the surface of the road in case of an accident. Therefore, the set of test norms and standards on motorcycle clothing are important to prevent and minimize the injuries of motorcyclists. The protective clothing for motorcyclists is subject to requirements and many aspects that must be respected and taken into account during the manufacturing process. Another problem is that these test procedures are time-consuming and relatively expensive. Developing tests to compare different test methods with the results of real accidents is important [11]. For example, 
according to the study by Bollschweiler et al., the test results for motorcycle protective clothing materials were partially different from the results obtained with standard test equipment [11]. As the results of the Rome et al. study show, the forces involved in some accidents exceed the limits prescribed by European standards for motorcycle protective clothing. This means that the failure rate of protective clothing found in the study points to the need for improved quality control [12].

A significant improvement in the consequences of an accident can therefore be achieved by appropriately assigned protective clothing [13-15]. The warmer days are problematic, however, because motorcyclists often suffer from very serious injuries during these days, as the safety of some drivers is neglected due to the weather-related heat. Thinner and mostly synthetic textiles are worn for "protection", mainly from the area of leisure wear. The highest number of motorcycle accidents occurs in summer, while in winter the lowest number is recorded [16]. One reason for this could be the heavy and not always comfortable and poorly breathable motorcycle clothing, which in hot summer temperatures is often waived to wear.

The clothing of the motorcyclist is currently the only buffer to be able to offer the rider sufficient protection, thus the well-protective clothing is subject to certain requirements and many aspects that must be taken into account in the manufacturing process, but compromises should be made [13,14]. There will certainly not be any clothing that protects well and is also pleasantly airy at the same time. Especially in hot temperatures, many motorcyclists feel overheated and are not comfortable in heavy motorcycle clothing. Furthermore, the overheating of the body leads to significant thermal stress on the body and has impact on motorcyclists' cognitive and psychophysical functioning [17]. In addition to these factors, other factors such as the behavior of drivers in traffic, driving speed, road conditions, etc. also play a role [17-21]. Due to excessive abrasion during braking by clothing, the motorcyclist can roll over, which should be avoided. Conversely, the clothing should not lead to endless slipping, which could lead to a collision with another vehicle or a guardrail $[8,9]$.

Publications on the topic of safety tests of protective motorcycle clothing are rare information that can only be found very sporadically in the form of a book. For the safety of motorcyclists, it is important that different testing methods and approaches are used to test motorcycle clothing, because there is no method that realistically simulates different aspects of motorcycle crashes and the behavior of protective clothing. Most testing methods require a costly and time-consuming effort and can only be performed in specialized laboratories.

In this study, a simple and cost-effective device for testing the abrasion resistance of protective clothing was developed. To test the abrasion resistance of the materials, a self-built test setup with a commercially available grinding machine was used. In order to determine a difference between a slipping motorcyclist and a fallen motorcyclist, both cases are simulated in test series with and without a fall, i.e., once with an impact and once excluding impact. Different textiles and leather types with and without coating were tested and compared. The results show that textiles achieved favorable results and that expensive materials should not always be used. It was also found that the force of an impact significantly changes the results. This developed test method can be an alternative for simple and inexpensive motorcycle protective clothing inspection.

\section{Materials and Methods}

A wet and dry grinding machine (Einhell, BT-WD 150/200, isc Gmbh, Landau/lsar, Germany) served as the basis for the construction of the test setup. The rotational speed of the machine specified by the manufacturer of the grinding machine was $1.37 \mathrm{~m} / \mathrm{s}$. Stabilizing parts made of wood (Multiflex board, plywood, BAUHAUS E-Business Gesellschaft für Bau- und Hausbedarf GmbH \& Co. KG, Mannheim, Germany) with thickness of $15 \mathrm{~mm}$ and surface finish wood sanded were used as stabilization elements. Figure 1 shows the self-built test setup. 


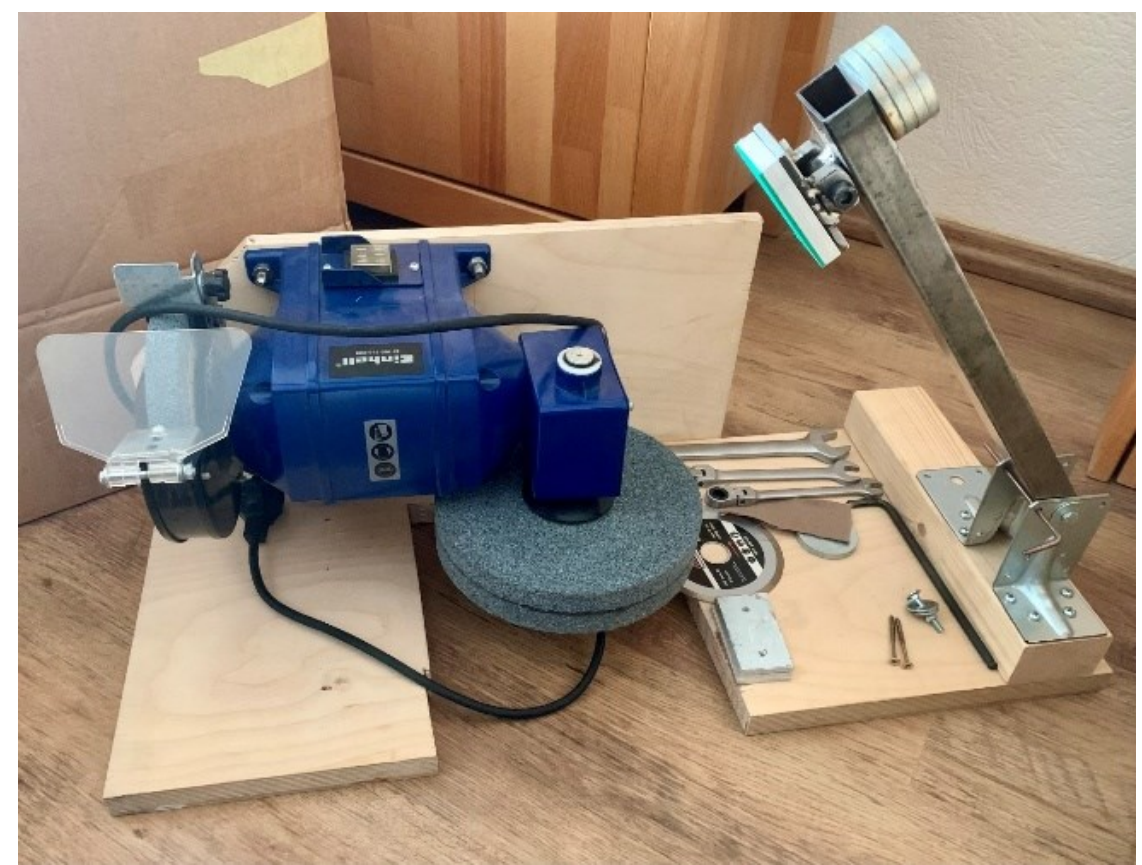

Fig. 1 A self-built test setup for testing the abrasion resistance of protective clothing.

An aluminum oxide grinding wheel (Silverleine, Group Silverline Limited, Yeovil, Great Britain) with the size of $\varnothing 200 \mathrm{~mm} \times \varnothing 20 \mathrm{~mm}, 31.75 \mathrm{~mm}, \mathrm{~K} 36$ was used as a rubbing element (see Fig. 2a). The drop arm was assembled from aluminum and steel parts and has a mass of $940 \mathrm{~g}$ and the height to the grindstone is $30.5 \mathrm{~cm}$ (see Fig. 2b). In order to distribute the pressure on the sample more evenly, the sample holder was coated with a sponge (3M Scotch Brite hand pad $96.3 \mathrm{M}$, test area $70 \mathrm{~mm} \times 40 \mathrm{~mm}$ ). Figure 2 shows the components of the self-build test setups such as grinding wheel (Fig. 2a), drop arm (Fig. 2b) and sample holder (Fig. 2c).

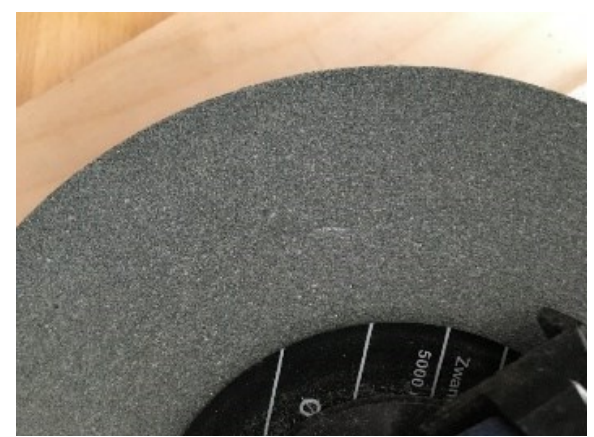

(a)

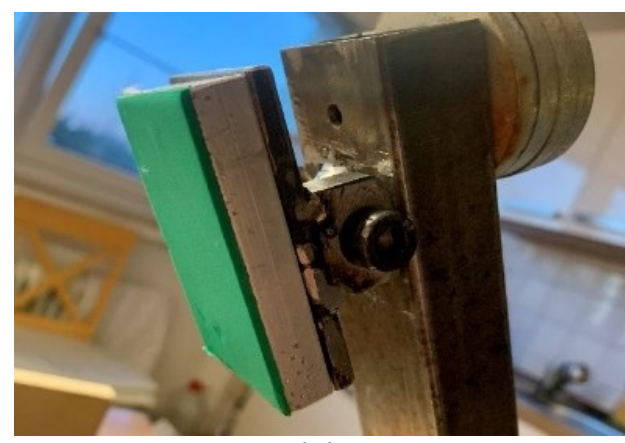

(b)

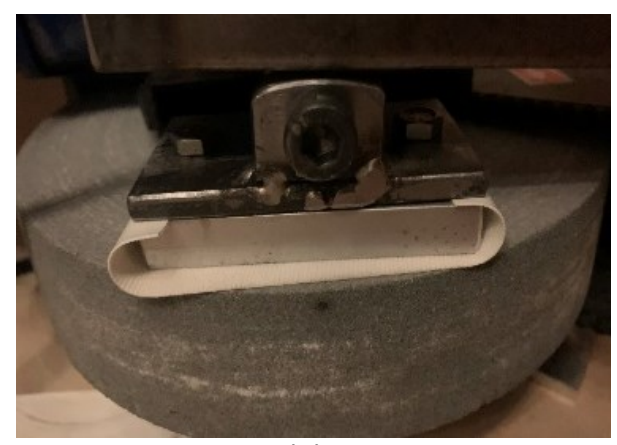

(c)

Fig. 2 (a) Grinding wheel; (b) Drop arm with sponge; (c) Sample holder

The focus of the experiments is to simulate as real as possible processes with the simplest means. The first case with impact is performed with a fall, in which case the drop arm with the sample attached to it will fall down onto the grindstone. In the second case, the sample attached to the drop arm is carefully placed on the grindstone, and only then the testing is started. Therefore, the grinding wheel was chosen similar to the surface roughness of the road to represent as real as possible the accompanying circumstances. The comparison between sliding and falling motorcyclists was simulated and differences in the abrasion resistance of the samples were determined. These two cases are intended to illustrate the simulations of a motorcyclist in an accident with and without impact on the road.

In the following, the explanations of the calculations are presented. The force on the drop arm, without the fall on the road, was defined as $9.22 \mathrm{~N}$. 
The area of the abrasive surface on the sample holder was set to $0.0028 \mathrm{~m}^{2}$ (see Fig. $2 \mathrm{~b}$ ). As a result, in this case the simulation results in a pressure of $3.292 \mathrm{kPa}$,

$$
9.22 \mathrm{~N} / 0.0028 \mathrm{~m}^{2}=3.292 \mathrm{kPa} \text {, }
$$

which is lower by a factor $\sim 5.7$ than described in the EN 17092-1 standard, where a pressure of $18.75 \mathrm{kPa}$ is specified.

$$
18.75 \mathrm{kPa} / 3.292 \mathrm{kPa}=\sim 5.7
$$

In order to determine the duration of the simulation, the factor $\sim 5.7$ and the average meters covered by a casualty on clothing on the road were combined. It was assumed that a motorcyclist victim slides a distance of 100 meters on the road until stopping. These 100 meters were multiplied by a factor of $\sim 5.7$ to generate loads at least similar to the pressure of $18.75 \mathrm{kPa}$ in the EN 17092-1 standard and so $570 \mathrm{~m}$ were defined.

$$
100 \mathrm{~m} \cdot 5.7=570 \mathrm{~m}
$$

To determine the time duration of the tests, 570 meters were divided by $1.37 \mathrm{~m} / \mathrm{s}$, which represents the rotation speed of the grinding wheel, and 416 seconds were determined.

$$
570 \mathrm{~m} /(1.37 \mathrm{~m} / \mathrm{s})=416 \mathrm{~s}
$$

To remove the abrasion film after each test series, the grindstone was first roughly cleaned with a brush and then vacuumed (AEG Vacuum cleaner LX7-2-CR-A, 750 Watt, Electrolux Hausgeräte $\mathrm{GmbH}$, Nürnberg, Germany) to remove residual sample material from the surface. In each test series, three samples were tested and the grinding stone was changed for each new test series. Table 2 shows the overview of natural and artificial leather and their specifications used in the test series. The textiles used for the abrasion resistance tests and their specifications are listed in Table 3.

Table 2. Overview of natural and artificial leather samples used in the test series.

\begin{tabular}{llcc}
\hline Sample & Composition & $\begin{array}{l}\text { Thickness } \\
(\mathrm{mm})\end{array}$ & Areal weight $\left(\mathrm{g} / \mathrm{m}^{2}\right)$ \\
\hline Kangaroo leather & Natural leather & 0.9 & 520 \\
\hline Skate leather & Natural leather & 1.8 & 2500 \\
\hline Artificial leather (brown) & Knitted Fabric + coating & 0.7 & 920 \\
\hline Artificial leather (dark green) & Knitted Fabric + coating & 0.8 & 700 \\
\hline Artificial leather (black) & Coating & 0.9 & 1130 \\
\hline
\end{tabular}

Table 3. Overview of textile samples used in the test series.

\begin{tabular}{llcc}
\hline Sample & Composition & Thickness $(\mathrm{mm})$ & Areal weight $\left(\mathrm{g} / \mathrm{m}^{2}\right)$ \\
\hline CORDURA® Air & Knitted fabric & 0.6 & 250 \\
\hline CORDURA® 500 (laminated) & Woven fabric + knitted fabric & 1.1 & 330 \\
\hline CORDURA® 500 (coated) & Woven fabric + coating & 0.5 & 260 \\
\hline Dynatec Reflex & Woven fabric + coating & 0.5 & 350 \\
\hline CORDURA® MISANO & Woven fabric + knitted fabric & 0.6 & 320 \\
\hline CORDURA® 2000 (coated) & Woven fabric + coating & 0.9 & 410 \\
\hline Keprotec & Knitted fabric & 0.9 & 550 \\
\hline SuperFabric $\circledast$ & Woven fabric + coating & 1.1 & 265 \\
\hline
\end{tabular}


As shown in Figures 3 and 4, leather and textiles have different surface morphologies ranging from relatively smooth to rough with relief and texture.

Microscopic images were captured using VHX-600D optical digital microscope (Keyence, Neu-Isenburg, Germany). The photographs were taken with Nikon DX (Nikon Corp., Japan).

\section{Results and discussions}

Table 4 shows the observations in abrasion resistance tests for leather. The differences between abrasion resistance tests on the surfaces of the leather samples with fall simulation and without are not as pronounced for leather as for textiles (see Table 4 and Table 5). All leather samples show good abrasion resistance with fall simulation and without, whereas tests with textiles show visible differences.

Table 4 Overview of abrasion resistance test results for natural and artificial leather samples.

\begin{tabular}{|c|c|c|c|c|c|c|}
\hline Sample & Time (s) & Length (m) & Observations & Time (s) & Length (m) & Observations \\
\hline \multicolumn{4}{|c|}{ Simulation with impact } & \multicolumn{3}{|c|}{ Simulation without impact } \\
\hline $\begin{array}{l}\text { Kangaroo } \\
\text { leather }\end{array}$ & 416 & 570 & $\begin{array}{l}\text { Clear abrasion and depth } \\
\text { pressure spot }\end{array}$ & 416 & 570 & Abrasion incl. abrasion pattern \\
\hline $\begin{array}{l}\text { Skate } \\
\text { leather }\end{array}$ & 416 & 570 & $\begin{array}{l}\text { Minimal visible abrasion (light } \\
\text { abrasion film) }\end{array}$ & 416 & 570 & $\begin{array}{l}\text { Minimal abrasion (light } \\
\text { abrasion film) }\end{array}$ \\
\hline $\begin{array}{l}\text { Artificial } \\
\text { leather } \\
\text { brown }\end{array}$ & 416 & 570 & $\begin{array}{c}\text { Abrasion incl. abrasion } \\
\text { pattern (strong abrasion film) }\end{array}$ & 416 & 570 & $\begin{array}{l}\text { Abrasion incl. abrasion pattern } \\
\text { (strong abrasion film) }\end{array}$ \\
\hline $\begin{array}{l}\text { Artificial } \\
\text { leather } \\
\text { green }\end{array}$ & 416 & 570 & Increased abrasion & 416 & 570 & Less abrasion \\
\hline $\begin{array}{l}\text { Artificial } \\
\text { leather } \\
\text { black }\end{array}$ & 416 & 570 & $\begin{array}{l}\text { Abrasion incl. abrasion } \\
\text { pattern (light abrasion film) }\end{array}$ & 416 & 570 & $\begin{array}{l}\text { More abrasion incl. abrasion } \\
\text { pattern (light abrasion film) }\end{array}$ \\
\hline
\end{tabular}

Figure 3 shows an overview of the light microscope images and photographs of the natural and artificial leather samples after the abrasion resistance test series. All artificial leather samples had achieved similar results after the abrasion resistance test and therefore only one sample of artificial leather is shown in Figure 3.

The microscopic images $3 a, 3 b$ and $3 c$ show the surfaces of leather samples before the test series. To see clearly the differences in surface morphology, images $3 d, 3 e$ and $3 f$ show the untreated area on the left and an abraded area after the test on the right. Photographs $3 \mathrm{~g}$, 3h and $3 \mathrm{i}$ show the original reference sample, the sample after the abrasion resistance test with impact and the sample without impact. On the left is the original sample, in the middle the sample after the fall simulation and on the right the simulation without fall (see Fig. $3 g$, $3 \mathrm{~h}$ and $3 \mathrm{i}$ ). It can be stated that all leather samples have passed the abrasion resistance test series and no erasures or cracks are visible.

The overview of the results of the abrasion resistance test series for textile samples is presented in Table 5. 

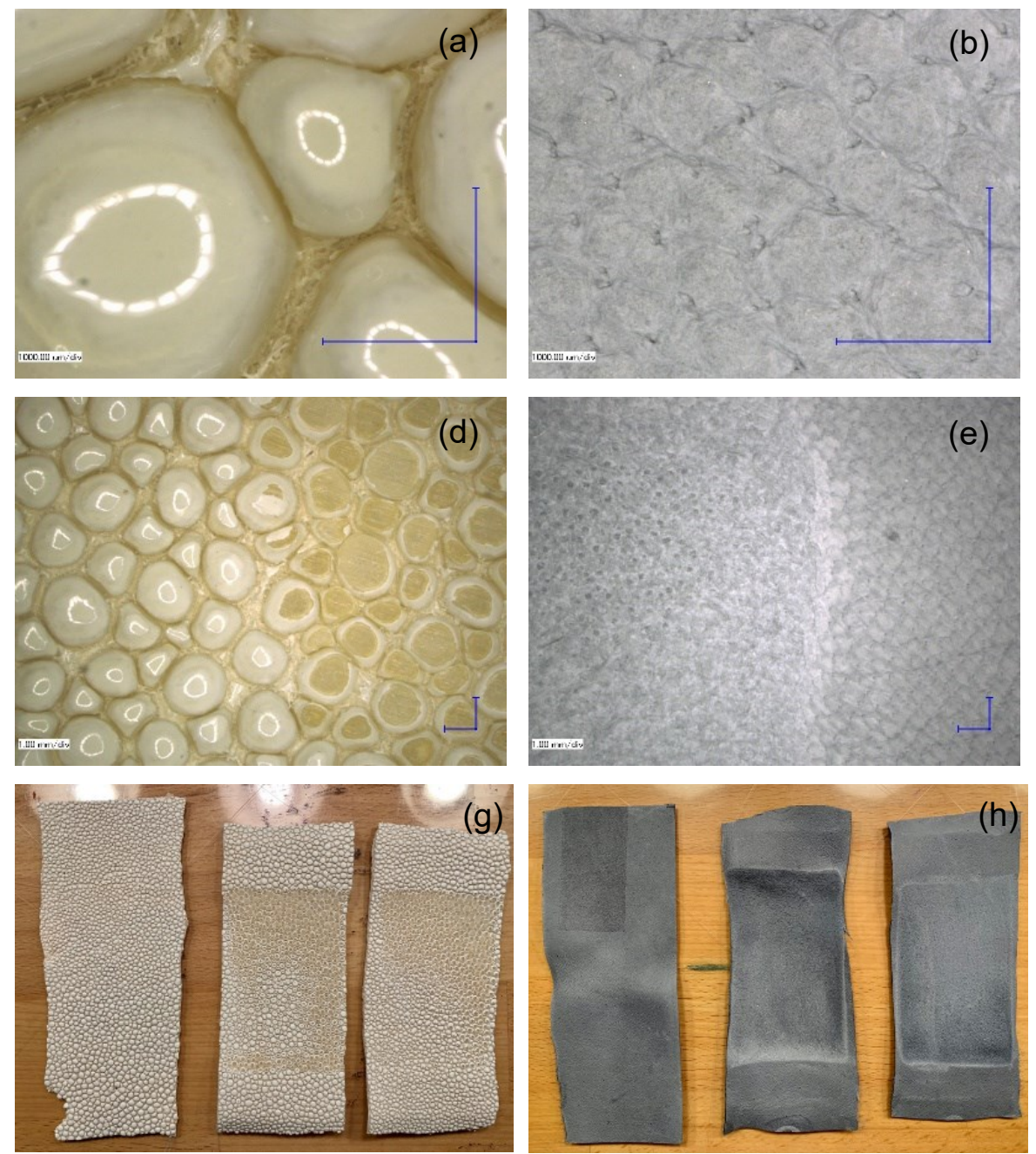
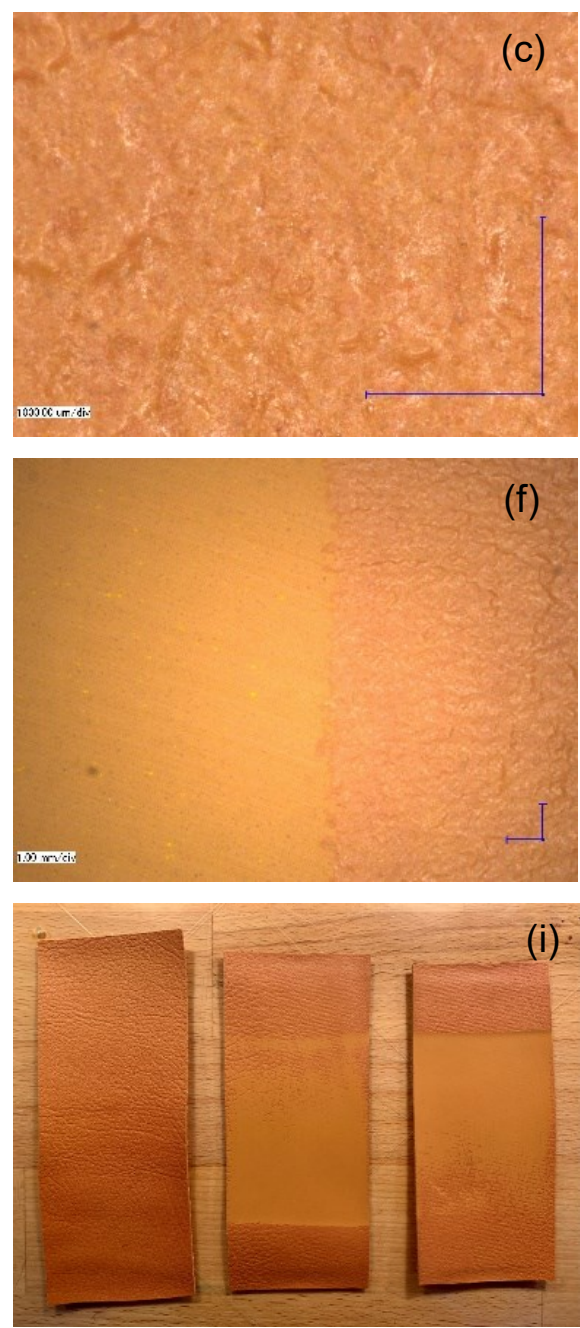

Fig. 3 Overview of the leather samples: microscopic images 3a (Skate leather), 3b (Kangaroo leather) and $3 c$

(Artificial leather brown) show the reference leather samples; microscopic images $3 d$, $3 e$ and $3 f$ show the difference between abraded areas and untreated areas; photographs $3 \mathrm{~g}$, $3 \mathrm{~h}$ and $3 i$ show original sample on the left, after abrasion test with impact in the middle and on the left without impact.

Table 5. Overview of abrasion resistance test results for textile samples.

\begin{tabular}{|c|c|c|c|c|c|c|}
\hline Sample & Time (s) & Length (m) & Observations & Time (s) & Length (m) & Observations \\
\hline \multicolumn{4}{|c|}{ Simulation with impact } & \multicolumn{3}{|c|}{ Simulation without impact } \\
\hline Cordura $\circledR_{\text {Air }}$ & 0 & 0 & Cracked on impact & 20 & 27.4 & Sideward abrasion, with a tear \\
\hline $\begin{array}{l}\text { Cordura } \circledR 500 \\
\text { laminated }\end{array}$ & 386 & 529 & $\begin{array}{l}\text { Damaged on the sides, } \\
\text { increased fluff }\end{array}$ & 416 & 570 & $\begin{array}{l}\text { Abrasion incl. lateral fraying } \\
\text { and fluffing }\end{array}$ \\
\hline $\begin{array}{l}\text { Cordura } \circledR 500 \\
\text { coated }\end{array}$ & 416 & 570 & $\begin{array}{l}\text { Significant abrasion incl. } \\
\text { abrasion pattern }\end{array}$ & 416 & 570 & $\begin{array}{l}\text { Abrasion incl. pattern of } \\
\text { abrasion }\end{array}$ \\
\hline $\begin{array}{l}\text { Cordura } \\
\text { Misano 3LG }\end{array}$ & 416 & 570 & $\begin{array}{l}\text { Abrasion incl. abrasion } \\
\text { pattern \& fluffing }\end{array}$ & 416 & 570 & $\begin{array}{l}\text { Abrasion incl. formation of } \\
\text { fringes }\end{array}$ \\
\hline $\begin{array}{l}\text { Cordura } 尺 2000 \\
\text { coated PU }\end{array}$ & 416 & 570 & $\begin{array}{l}\text { Abrasion incl. increased fluff } \\
\& \text { formation of fringes }\end{array}$ & 416 & 570 & Abrasion incl. increased fluff \\
\hline $\begin{array}{l}\text { Schoeller®- } \\
\text { Keprotec }\end{array}$ & 416 & 570 & Abrasion incl. less fluff & 416 & 570 & Abrasion incl. less fluff \\
\hline $\begin{array}{l}\text { Schoeller@- } \\
\text { DYNATEC- } \\
\text { Reflex }\end{array}$ & 416 & 570 & Abrasion incl. less fringes & 416 & 570 & Abrasion incl. very less fringes \\
\hline SuperFabric $®$ & 416 & 570 & Minimal abrasion & 416 & 570 & Minimal visible abrasion \\
\hline
\end{tabular}


In the case of textile samples, most textiles effectively passed the abrasion resistance test series, but in case of CORDURA® Air and CORDURA® 500 (laminated), the tests were stopped after a few seconds due to tearing or heavy abrasion. An impact that occurs during a motorcycle accident has a major influence on the abrasion resistance of the motorcycle clothing. Figures 4 and 5 show the tested samples CORDURA® Air and CORDURA® 500 (laminated).

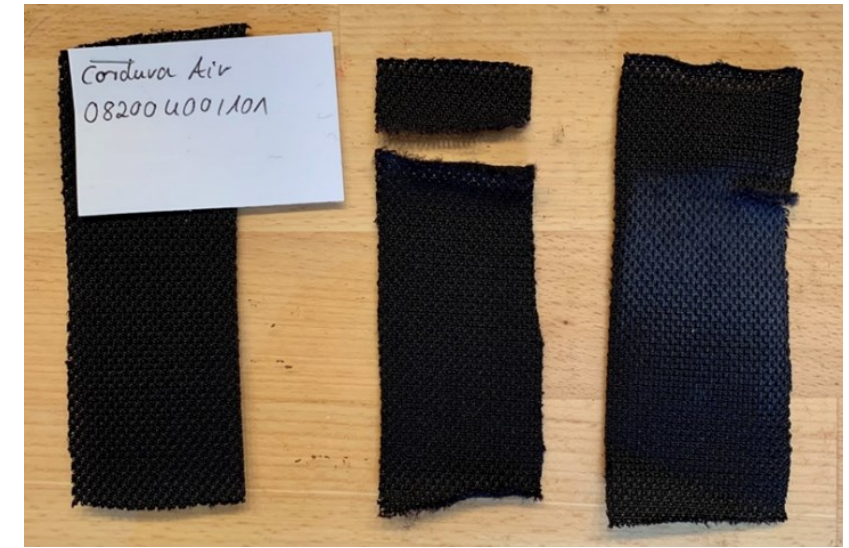

(a)

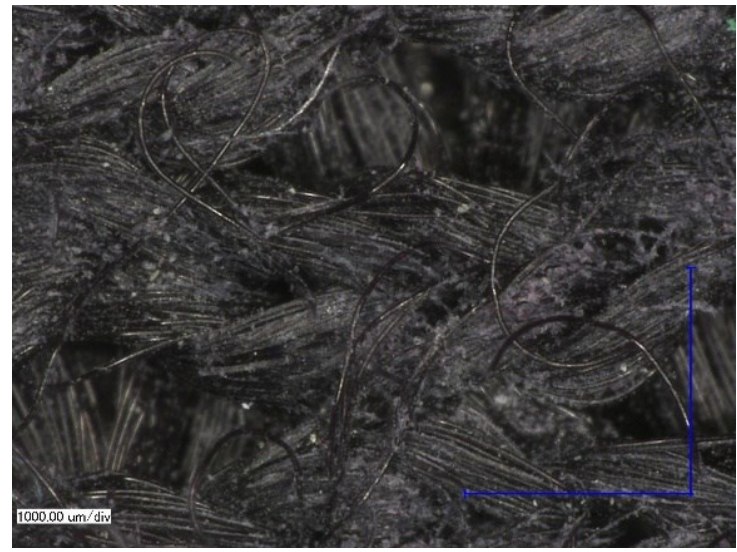

(b)

Fig. 4 Photograph and microscopic image of CORDURA® Air: (4a) reference sample, damaged sample due to the impact simulation and sample after the abrasion test without a fall simulation; (4b) microscopic image of the abraded surface.

On the left the reference sample is presented, in the middle a sample after a fall simulation and on the right the sample after the abrasion test without impact (see Fig. 4a). The sample after the fall simulation in the middle clearly shows that the fabric was torn off. This occurred directly after impact, whereas in the simulation without fall, a tear formed only after 27.4 meters on the right above the sample. The microscopic image shows the surface morphology of the sample CORDURA® Air and some chaotically oriented fibers and abrasion film (see Fig. 4b).

Figure 5 shows the result of the test series of CORDURA $₫ 500$ (laminated). CORDURA $₫ 500$ (laminated) in addition to CORDURA $®$ Air is also one of the textile samples that exhibited severe damage before reaching the 570 meters specified in test conditions. In this case, the sample with the impact after 529 meters shows a strong lateral damage (see Fig. 5). The sample without the impact, however, has withstood the entire $\mathbf{5 7 0}$ meters, where fluff and lateral fraying can be observed (see Fig. $5)$.

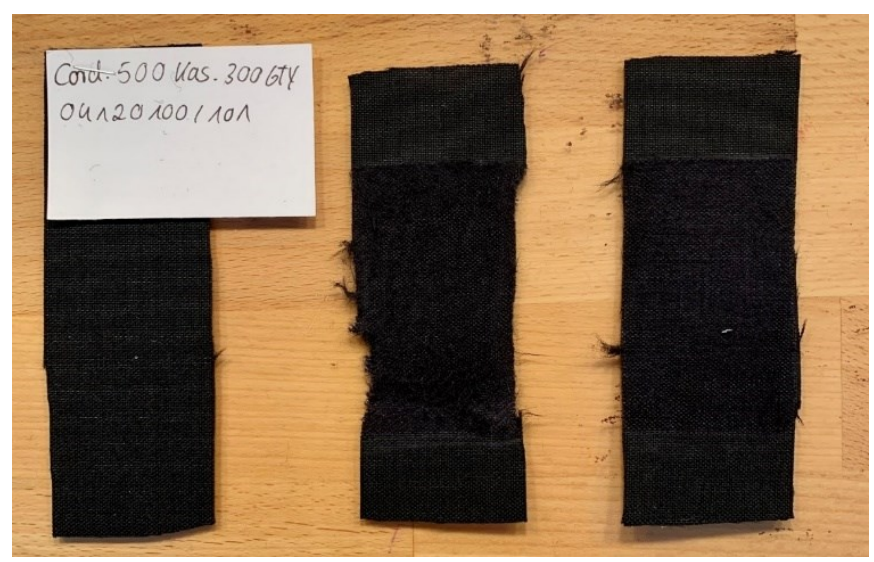

(a)

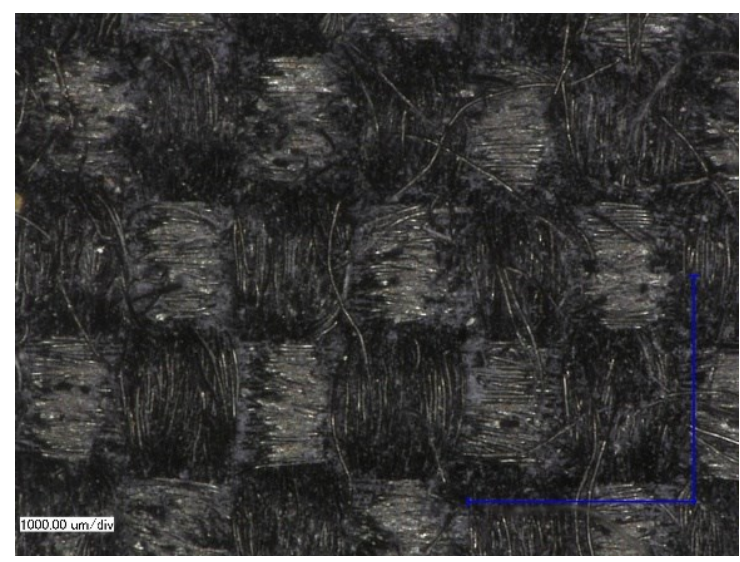

(b)

Fig. 5 The photograph and microscopic image of the CORDURA® 500 (laminated): (a) reference sample, damaged sample due to the impact simulation and sample after the abrasion test without a fall simulation; (b) microscopic image of the abraded surface. 
In general, with the exception of CORDURA ${ }^{\circ}$ Air and CODURA® 500 (laminated), all textiles have passed the abrasion test without premature interruption. Figure 6 shows the Schoeller $@-K e p r o t e c ~(6 a)$, Schoeller $®-D y n a t e c$ Reflex (6b) and SuperFabric $(6 c)$ in more detail. The microscopic images $6 a, 6 b$ and $6 \mathrm{c}$ show the textile samples before the test series.
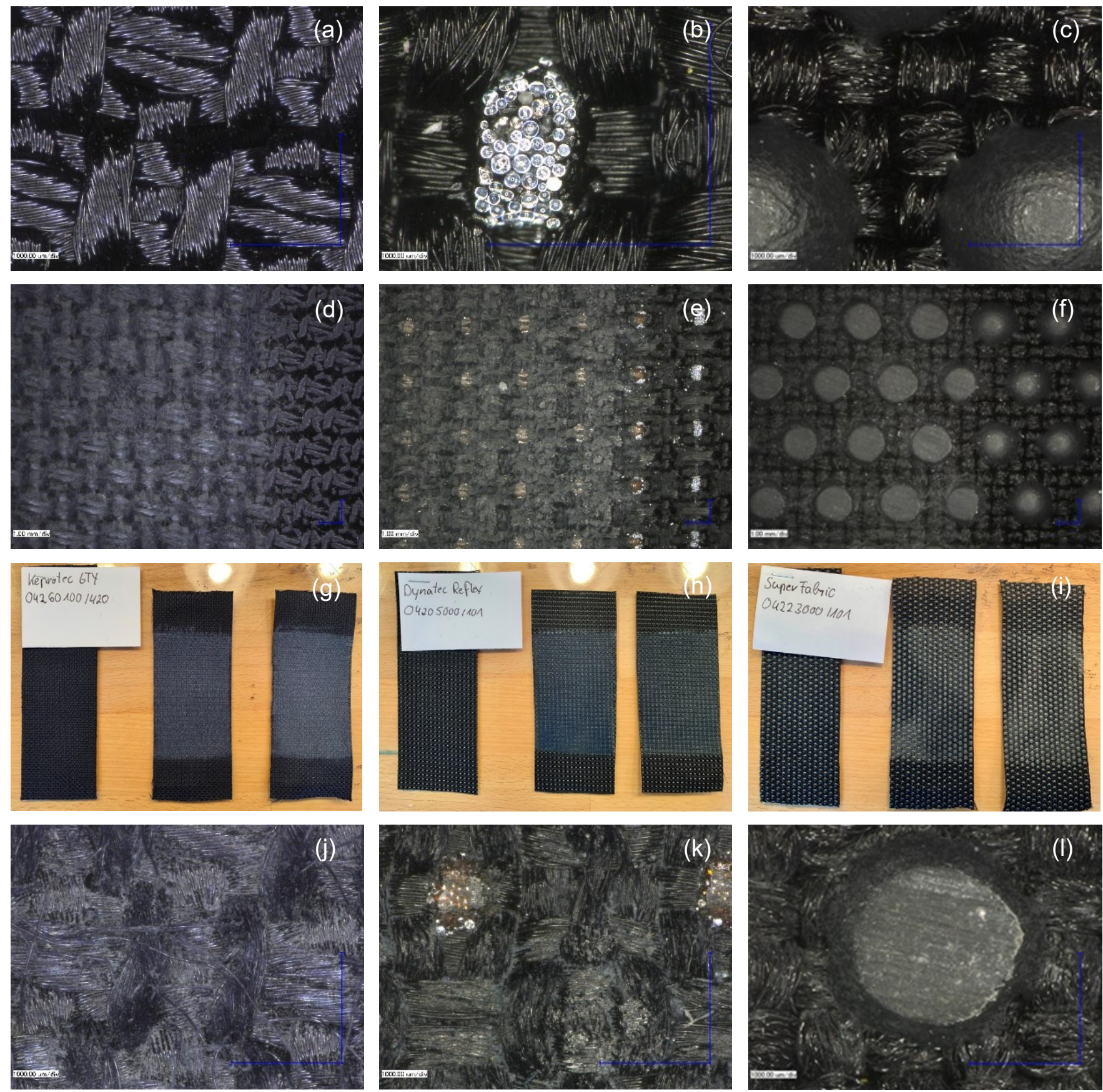

Fig. 6 The overview of the Schoeller®-Keprotec (6a), Schoeller®-Dynatec Reflex (6b) and SuperFabric ${ }^{\circledR}(6 c)$ reference samples; microscopic images $6 d, 6 e$ and $6 f$ show abraded and unabraded (hidden) areas; photographs $6 \mathrm{~g}, 6 \mathrm{~h}$ and $6 \mathrm{i}$ show reference sample on the left, after abrasion test with impact in the middle and on the left without impact; microscopic images of the abraded surface are presented in $6 j, 6 \mathrm{k}$ and $6 \mathrm{l}$.

The glass beads in the middle of the textile fabric can be seen particularly well in Fig. $6 \mathrm{~b}$, which represent the fabric construction of the Schoeller®-Dynatec Reflex as well the guard plates on the surface of the SuperFabric $®$ in Figure $6 c$ are clearly visible. The microscopic images $6 \mathrm{~d}, 6 \mathrm{e}$ and $6 f$ show the surface morphology after the abrasion test on the left and the untreated side of the sample on the right. In photographs $6 \mathrm{~g}, 6 \mathrm{~h}$ and $6 \mathrm{i}$, the original reference sample, the sample after the abrasion 
resistance test with impact, and the sample without impact can be seen. The microscopic images $6 \mathrm{j}, 6 \mathrm{k}$ and $6 \mathrm{I}$ show the surfaces of textiles with clearly visible abrasion films as well as the individual fibers that were torn out. The glass pearls are only partially present at Schoeller®-Dynatec Reflex (see Fig. 6k) and the guard plate is almost completely worn off (see Fig. 6l) after test series.

Finally, it can be stated that for Schoeller®-Keprotec sample (see Fig. $6 \mathrm{~g}$ ) no clear difference in abrasion resistance can be seen in the samples with the impact simulation and without. In the case of Schoeller®Dynatec Reflex, more fringes were frayed in the sample with the impact than in the sample without the impact (see Fig. 6h). The SuperFabric $®$ performs best of all results in the area of abrasion resistance (see Fig. 6i). The guard plates on the surface of the textile fabric (see Fig. 6c and 6i) are not only very similar to skate leather (see Fig. 3a and $3 \mathrm{~g}$ ), they also lead to the same result, in which barely visible abrasion is noticeable and the fabric does not remain damaged even though the guard plates are abraded. In conclusion, it can be stated that almost all textile fabrics had good abrasion resistance and, in comparison to leather, are a good alternative for use in motorcycle protective clothing.

According to our research, there is no optimal test method for motorcycle clothing that closely simulates a real accident and takes all aspects into account. It is difficult to simulate the real accident conditions to see how the motorcycle clothing and the materials used behave, because these circumstances cannot easily be carried out on a laboratory scale. Therefore, it is of great interest to establish and apply different methods for testing motorcycle clothing for the textile industry in all steps in textile chain and to consider as many aspects as possible that occur during an accident in order to make the motorcycle clothing safer and reduce injuries.

The method proposed in this study also cannot reflect all the variations that occur in a real accident. But this test method is inexpensive and simple in design, and takes into account the fall of the motorcycle, which, for example, does not occur in other method such as EN 13595. In addition, with this method a new grindstone is inserted after each test in order not to falsify the results of the abrasion tests with abrasion film, which collects on the surface after a while. This is an advantage over the Darmstadt method, where an abrasion film collects on the surface of the road and influences the slip resistance. Therefore, the method proposed in this study can be beneficial for small and medium enterprises as a supplement or for pre-testing, as it is simple and not costly compared to other testing methods, or can be used in the textile industry to act as a complement to other testing methods.

\section{Conclusion}

Motorcyclists often suffer serious injuries in accidents, especially in high temperatures during summer months when they are wearing thinner garments. Typical test procedures for protective clothing often cannot accurately represent a real accident situation, and the scientific literature on this topic is relatively limited.

In this study, a fast, simple, and cost-effective test device for testing the abrasion resistance of motorcycle protective clothing was developed. A self-constructed test setup with a commercial grinding machine was used and various textile fabrics and leather samples were tested for abrasion resistance. Most leather and man-made textile fabric samples (except Cordura ${ }^{\circledR}$ Air and Cordura ${ }^{\circledR} 500$ (laminated)) showed effective abrasion resistance in most cases. This means that not only leather, but also textiles are well suited for protective clothing for motorcyclists. Man-made textile fabrics offer better air permeability, are lightweight, more flexible than leather and washable, and therefore offer much better clothing comfort.

These results clearly show that there is a need for inexpensive equipment and test methods to test the abrasion resistant motorcycle clothing with a reliable method. Furthermore ideally, more than one test rig should be used to simulate different possible accident situations and not only static tests should be performed in the laboratory. 


\section{Acknowledgements}

The authors acknowledge personal funding from the internal PhD funds of Bielefeld University of Applied Sciences, Erasmus+ and the internal funds for female students in STEM programs at Bielefeld University of Applied Sciences.

\section{References}

[1] Boon Hong Ang, Shaun Wen Huey Lee, Jennifer Oxley, Khai Khun Yap, Keang Peng Song, S. B. Kamaruzzaman, A. V. Chin, K. M. Tan, H. M. Khor, and Won Sun Chen. 2019. Self-regulatory driving and riding practices amongst older adults in Malaysia. Transp. Res. Part F Traffic Psychol. Behav. 62, 782-795. DOI: https://doi.org/10.1016/j.trf.2019.03.014.

[2] Fábio A.O. Fernandes, Ricardo J.Alves de Sousa, Mariusz Ptak, and Gonçalo Migueis. 2019. Helmet design based on the optimization of biocomposite energy-absorbing liners under multi-impact loading. Appl. Sci. 9, 4, 1-26. DOI: https://doi.org/10.3390/app9040735.

[3] Shriram Mukunthan, Jochen Vleugels, Toon Huysmans, Kalev Kuklane, Tiago Sotto Mayor, and Guido De Bruyne. 2019. Thermal-performance evaluation of bicycle helmets for convective and evaporative heat loss at low and moderate cycling speeds. Appl. Sci. 9, 18. DOI: https://doi.org/10.3390/app9183672.

[4] Miguel Araujo, Eduardo Illanes, Evelina Chapman, and Eugênia Rodrigues. 2017. Effectiveness of interventions to prevent motorcycle injuries: systematic review of the literature. Int. J. Inj. Contr. Saf. Promot. 24, 3, 406-422. DOI: https://doi.org/10.1080/17457300.2016.1224901.

[5] El Yamani Fouda, Mohamed Youssef, Sameh H. Emile, Hossam Elfeki, Waleed Thabet, Emad Abdallah, Ayman Elshobaky, Mohamed S. Toma, and Wael Khafagy. 2017. Pattern of major injuries after motorcycle accidents in Egypt: The Mansoura Emergency Hospital experience. Trauma (United Kingdom) 19, 1, 39-45. DOI: https://doi.org/10.1177/1460408616652924.

[6] Longina Madej-Kiełbik, Katarzyna Kośla, Dorota Zielińska, Edyta Chmal-Fudali, and Magdalena Maciejewska. 2019. Effect of accelerated ageing on the mechanical and structural properties of the material system used in protectors. Polymers (Basel). 11, 8. DOI: https://doi.org/10.3390/polym11081263.

[7] Lauren Meredith, Christopher Hurren, Elizabeth Clarke, Michael Fitzharris, Matthew Baldock, Liz de Rome, Jake Olivier, and Julie Brown. 2017. Validation of the abrasion resistance test protocols and performance criteria of EN13595: The probability of soft tissue injury to motorcycle riders by abrasion resistance of their clothing. J. Safety Res. 61, 1-7. DOI: https://doi.org/10.1016/j.jsr.2017.02.001.

[8] Motohart UK Ltd. 2016. CE-booklet-clothing-Curved.pdf. Harvey Combe, Killingworth, NE 12 6QQ. Available on: https://www.viperrider.com /eudoc17902 (accessed on October 28, 2021).

[9] Slovenski inštitut za standardizacijo. 2000. Slovenski Standard SIST EN 61310-3:2000. https://standards.iteh.ai/catalog/standards/sist/76ac0d7f-e1a3-4311-9f95-27768b6746a3/sist-en-61310-3-2008 (accessed on December 17, 2021).

[10] Beuth Verlag $\mathrm{GmbH}$. 2021. Avaliable on: https://www.beuth.de/de/erweitertesuche/272754!search?alx.searchType=complex\&searchAreald=1\&query=Motorradfahrer\&facets\%5B276612\% $5 \mathrm{D}=$ \&hitsPerPage $=10$ (accessed on October 21, 2021).

[11] Nicolai Bollschweiler, Sascha Marzen, and Andrea Ehrmann. 2018. New method to measure abrasion of motorcyclist protective clothing. Tekstilec 61, 3, 152-161. DOI: https://doi.org/10.14502/tekstilec2018.61.152161.

[12] Liz de Rome, Rebecca Ivers, Michael Fitzharris, Wei Du, Narelle Haworth, Stephane Heritier, Drew Richardson. 2011. Motorcycle protective clothing: Protection from injury or just the weather? Accident Analysis \& Prevention 43, 6,1893-1900. https://doi.org/10.1016/j.aap.2011.04.027.

[13] Bianca Albanese, Tom Gibson, Tom Whyte, Lauren Meredith, Giovanni Savino, Liz de Rome, Matthew Baldock, Michael Fitzharris, and Julie Brown. 2017. Energy attenuation performance of impact protection worn by motorcyclists in real-world crashes. Traffic Inj. Prev. 18, S1, S116-S121. DOI: https://doi.org/10.1080/15389588.2017.1311014.

[14] Rafael Ekmejian, Pooria Sarrami, Justine M. Naylor, and lan A. Harris. 2016. A systematic review on the effectiveness of back protectors for motorcyclists. Scand. J. Trauma. Resusc. Emerg. Med. 24, 1, 115. DOI: https://doi.org/10.1186/s13049-016-0307-3.

[15] Marco Giustini, Sabina Cedri, Marco Tallon, Paolo Roazzi, Rita Formisano, and Alessio Pitidis. 2014. Use of back protector device on motorcycles and mopeds in Italy. Int. J. Epidemiol. 43, 6, 1921-1928. DOI: https://doi.org/10.1093/ije/dyu209.

[16] Sayyed Hoseinian, S. H., Ebrahimzadeh, M. H., Peivandi, M. T., Bagheri, F., Hasani, J., Golshan, S., \& Birjandinejad, A. 2019. Injury Patterns among Motorcyclist Trauma Patients: A Cross Sectional Study on 4200 Patients. The Archives of Bone and Joint Surgery 7(4), 367-372. PMID: 31448315; PMCID: PMC6686071.

[17] Liz de Rome. 2019. Could wearing motorcycle protective clothing compromise rider safety in hot weather? Accid. Anal. Prev. 128, 240-247. DOI: https://doi.org/10.1016/j.aap.2019.04.011. 
[18]Eleni Petridou and Maria Moustaki. 2000. Human Factors in the Causation of Road Traffic crashes. Eur. J. Epidemiol. 16, 9, 819-826.

[19] Patrick Seiniger, Kai Schröter, and Jost Gail. 2012. Perspectives for motorcycle stability control systems. Accid. Anal. Prev. 44, 1, 74-81. DOI: https://doi.org/10.1016/j.aap.2010.11.018

[20] Mustafa Talib Yousif, Ahmad Farhan Mohd Sadullah, and Khairil Anwar Abu Kassim. 2020. A review of behavioural issues contribution to motorcycle safety. IATSS Res. 44, 2, 142-154. DOI: https://doi.org/10.1016/j.iatssr.2019.12.001.

[21] Dan Halbersberg and Boaz Lerner. 2019. Young driver fatal motorcycle accident analysis by jointly maximizing accuracy and information. Accid. Anal. Prev. 129, 350-361. DOI: https://doi.org/10.1016/j.aap.2019.04.016. 